University for Business and Technology in Kosovo

UBT Knowledge Center

Oct 28th, 1:00 PM - 2:30 PM

\title{
Aspects of Islamic Revival and Radicalization in the region of Middle East
}

Redi Papa

University for Business and Technology, redi.papa@ubt-uni.net

Follow this and additional works at: https://knowledgecenter.ubt-uni.net/conference

Part of the International Relations Commons

\section{Recommended Citation}

Papa, Redi, "Aspects of Islamic Revival and Radicalization in the region of Middle East" (2017). UBT International Conference. 316.

https://knowledgecenter.ubt-uni.net/conference/2017/all-events/316

This Event is brought to you for free and open access by the Publication and Journals at UBT Knowledge Center. It has been accepted for inclusion in UBT International Conference by an authorized administrator of UBT Knowledge Center. For more information, please contact knowledge.center@ubt-uni.net. 


\title{
Aspects of Islamic Revival and Radicalization in the region of Middle East
}

\author{
Redi Papa \\ UBT - Higher Education Institution, Lagjja KALABRIA p.n., 10000 Prishtina, Kosovo \\ redi.papa@ubt-uni.net
}

\begin{abstract}
The main objective of this topic is to provide a detailed panorama of the causes of Islamic Revival and radicalization of Islam, particularly in the region of Middle East. In this perspective, it's somehow puzzling to at the first sight that Arab World used to be a leader in the science, military and science, is now paradoxically a region characterized by unrest and turmoil. Contrary to the past decades where peace was a distinctive peculiarity of the region and economy flourished, now is overwhelmed by the phenomena of the Radicalization of Islam for political purposes and to come to power. The Arab world blames the western powers for their stagnation, poverty, and lack of improvement in a wide range of fields. This may be considered only some of the causes of Islamic Revival and radicalization. Lack of proper education illiteracy is an underlying factor that leads to extremism. As a result there have been founded numerous fundamentalist groups such as AlShaabab, Boko Harram, Hamas, Hezbollah and Islamic State which pose a potential threat to peace and democracy and have caused many victims as a result of terrorist attacks.
\end{abstract}

Keywords: Islamic Radicalization, radicalism, Middle East, fundamentalist organizations

\section{Introduction}

During the course of $20^{\text {th }}$ Century in the Middle and in many Islamic countries, the hopes for an illuminated future were quite subtle. Comparably, with the most eminent and permanent rival "Christianity", these countries were being consistently impoverished, weakened and dipped into ignorance. Undoubtedly, during the nineteenth and twentieth century, the dominance of the western countries was quite evident. The most remarkable scholars came up to the conclusion that the reforms must be mainly focused on three basic aspects in ; military, economy and politics. Disappointingly, the outcomes were insignificant and futile ${ }^{166}$.The struggles to attain political supremacy through modernization of army brought nothing but nothing but humiliating defeats, whereas the struggles for bringing opulence led to a further impoverishment of common people and excruciatingly corrupted economies. In the vast majority of Islamic countries the economy experienced shrinkage in all sectors of economy and they led entirely on fossil sources of energy. There have been carried out innumerable efforts to find solutions through setting up factories, improvement of education system, parliamentary system, but they resulted in failure. These are some major factors that have brought worrisome situation among the common people of those

${ }^{166}$ Bernard Lewis, “ Ku po shkojme , Islami, Perendimi, dhe Moderniteti", botim i "Shtepia Botuese e Librit dhe e Komunikimit”, 2004, pg. 240. 
countries. It sounded painful for Islamic countries to lose their pride of being many centuries were wealthy, powerful in a wide range of fields. Contrary to the previous centuries, when they leaded the economical development, science, respected the human rights, now they have to cope with misery. In this perspective its worth posing the question, "Who brought all this?" this is the prevailing question in this region. Long time ago, the most remarkable scholars blamed the Mongolian invasion as one of the underlying causes of turmoil, weakness of the eradication of Islamic civilization. But this argument was an assumption which was not based on scientifically proven facts ${ }^{167}$. The emergence of nationalism brought above new perceptions. The Arabians could no more blame the others for their problems. Turks blamed the Arabians for the turmoil caused in their country, while the Persians blamed the same Arabians, Turks and Mongolians as the underlying cause that brought forth the fall of their civilization.

The period of French and English hegemony during the nineteenth and twentieth century, served to shape and found the so-called the western imperialism. The political domination, economical, cultural and political domination had changed the face of the entire region and altered the life of the people. As matter of fact this had evoked new hopes and fears at the same time. The remarkable agreement Sykes-Picot sealed in 1916, was one of the most eminent milestones. ${ }^{168}$ This agreement was compiled and was comprised of in-depth plans to "shatter" the Middle East in certain spheres of influence, as a form of imperialist exploitation. Undoubtedly, these marked the first step of ruining their future, but this wave of imperialism was extended even broader including the vast majority of Asia. Nevertheless, the period of English and French reign was relatively small. Metastases of a "rotten" socio-political system were evident before the reign of western countries. Due to the fact that the reign of European powers was at some extent incorporated by America.

\section{Reforms for Islamic Revival in the Arab Realm}

In the course of nineteenth and twentieth century, the "Muslim Realm", started to lose the political independence, cultural identity, due to the invasions of Christians that came from Europe. These phenomena came due to the fact that Europeans had tremendously improved economical and technological capacities. The "Muslim Realm" was somehow subordinated by the Christians and this was a perceived as a violation of their aspirations. As the notable scholar Yevgenia Baraz states, that their main concern was if they would be able to cope with the western culture and ideology and were continuously striving for finding the mechanisms to fight against these ideology that was being imported in their countries. However one of the most effective and useful means to counter the western invasion was the so-called "Islamic Modernization". 169

Even though the gist of the problem in the "Arab Realm", is not closely related to Islam, many people think that the most appropriate solution could be found from Islam. As far as western Islam is concerned they, opt for a reform similar to that which took place in between the church and state. Consequently, due to the implementation of this reform many clerics were deprived from the right to impose their will to common people, in other words it means they deprived to exercise their

167 Ibid, pg. 241.

168 Article by Jean Pierre Lehmann, "The failure of Islam to reform", "The Globalist”, 2014.

${ }^{169}$ Yevgenia Baraz "Islamic Modernism, responses to western modernization, the Middle East" , Boston, 2010,pg.1 
clerical authority. This milestone marked the end of the papal domination of church. Contrary to this in Islam, there has never been a clerical hierarchy, and cannot be compared to Catholicism, Protestantism and other religious sects. The ruthless rulers might easily find a preacher or a priest to legitimate their power, the same thing is true even for the rebels.

Contrary to other countries in Middle East, Iran has founded a clerical institution, which is widely spread after the revolution of Khomeini. He has elaborated and well-organized the hierarchy and leaded with headed by a similar religious figure such as pope. The remarkable scholar Bernard Lewis suggests that this may lead to an Iranian reformation:

"It seems that during his rule Khomeini has carried out a sort of Christianization of Islamic institutions of Iran”.

Even why the theocracy of Iran seems rather a paradox, it can pave the path for a broader reform. In this point of view, it's not unexpected that the country that the country that misled the Middle East towards the course of Islamic Radicalization, to contribute to retreat it from the evil. However Iran is not capable to cope with modernity, only due to the fact that is a democracy. There is established weak unconsolidated democracy. Consequently, the as a result of this, all the power is concentrated on the hands of clergy and the appointed president Muhamet Khatami is nothing but a tool in their hands.

The example of Iran has induced many scholars such as Faared Zakaria argue that when Islamic governments come to power they tend to lose the legitimacy and appear to disgrace themselves in front of public. In this perspective it seems that when fundamentalist Islamic parties come to power they lose their glory and are often denigrated due to their immaturity carry out the right policies for their countries. ${ }^{170}$ To accomplish an in-depth analysis it would be of great significance to take as example such states as: Bangladesh, Pakistan, Turkey, and Iran.

Nevertheless, the key to solution must not necessarily seek in the religious reform, but even in the political and economical reforms. Many scholars are mistaken when they put the emphasis on the alteration of Islam. If we pass from a theoretical to a practical analysis, it would be worth mentioning some examples to illustrate this. Turkey, Bosnia, Malaysia and some other parts of Southern Asia have plenty modern of Muslim communities. Meanwhile in United States, Canada and Europe have considerable Muslim communities that have adapted to the lifestyle of respective countries. ${ }^{171}$

Islamic Fundamentalism, which is commonly portrayed as the political Islam, is only an integral part of a broad scope of contemporary practices, ideas, and Islamic rhetoric and a devotion of Islamic populations to Islam. Revival is widely perceived and conceptualized as a non-extremist and comprehensive perspective that originates from the region of Middle East.

The remarkable scholar John.L.Esposito has pointed out some of the underlying indicators of Islamic Revival according to his point of view;

There are many indicators that may have fostered the Revival such as; a strict obedience of religious rules, (a regular attendance of mosques, prayers, and fasting), a widespread launching of religious publications, a promotion of Islamic values, a revival of Sufism as a revival of mysticism. In addition to this, there has been witnessed a growth of governments, organizations, laws, banks, services of social well-being and Islamic-oriented social institutions. Moreover the vast majority of

170 Faared Zakaria e "Ardhmja e Lirise", botim i "Instituti i Dialogut dhe Komunikimit", 2004,pg.34

171 Samuel Huntington Perplasja e Qyteterimeve dhe riberja e rendit boteror, "Shtepia Botuese", Logos 2004, pg.170 
rulers and governments, including secular states such as Turkey, Tunisia are becoming aware of the potential that derives from Islam, and seriously concerned about the Islamic cases.

A notable Islamic scholar Ali.E.Hillal Desouki, considers all this as a struggle for re-establishing the Islamic Right instead of the western right. This can be merely noticed by a vast and wide spread of Islamic education in the school system and in the consistent attempts of Islamic states to cooperate between each other and promote their values in international level. ${ }^{172}$

As far as the political approach is concerned, "Islamic Revival", resembles to Marxism, with its sacred writings, providing a panorama of society that is beyond reality and on verge of perfection, inability to accept the concept of nation and state. The existence Islamic state of Iraq is the best example to draw parallels that witness the gap between European Christianity and Islam. Contrary to Christian countries that have undertaken reforms culminating in the division of state from church, nothing like this is witnessed in the Arab world.

The lack of reformism has given birth to radicalism. As the remarkable scholar Robin Right argues, radical Islam is in its substance a political agenda that aims to attain its goals through violence, and they follow the example of Iran. However the vast majority of Muslim government's make the difference between the true Islam and radicalism. In this context, it's worth emphasizing that the secular state continuously had to cope with permanent struggles to survive and fight against movements that aimed to come to power with the platform of "Islamic Revival". ${ }^{173}$ This can be easily illustrated by the example of Sudan and Iraq where the radical governments misled the countries in the wrong direction. Obviously, Islam is often manipulated by governmental authorities to bear political benefits, use it as a tool to achieve geopolitical objectives and to fight against the opposition of their respective countries. The struggles of authoritarian governments such as Algeria to oppress the spread of radical Islam among population have failed to fulfill its mission.

Undoubtedly, this wave of Islamization has not outlined quite abruptly, but as a consequence of a wide range factors. In course of the last decade there has been witnessed an increase in the number religious-based schools particularly in Egypt, Mali and Pakistan. ${ }^{174}$ These schools point out the lack of national education, sometimes are even being financed by petro-dollars. The number of Taliban students that participated in Pakistan seminars in 1975, was approximately 100.000, while in 1998 this number boosted to 540,000-570,000 students. The number of institutes (including elementary and high schools), which were founded by Al-Azhar in Egypt increased from 1855 in 1986 to 4314. In the elementary schools this number varied from 920-2300. During the last decades in Morocco there has been witnessed an increase in the number of dissertation in religious sciences was far to higher compared to those in human sciences and literature. Many states have admitted to reform Islam and the Islamic Right as a preventive measure to prevent the further growth of radical Islam particularly after 1979. The Article 2 of Egyptian Constitution, stipulates that Shari at is the main source of the Right. The 1983. Pakistan enacted in 1985 "Shari at Bill". There are many similar examples that have applied this approach, such as Algeria etc.

The Courts that have implemented Shari at in Pakistan have accepted to investigate processes of Blasphemy. Islamization of the Right has provided the conservator environments to fight for their issues, by judicial means. In Pakistan many Christians have been punished for Blasphemy. In this perspective implementation of Sheri at in a modern state is quite problematic and inadmissible, due to the fact that Shari at is not a system of positive Right but a entirety of norms that a judge is obliged to implement in specific situations. In relevance to this, we can reason out that reIslamization has been directly induced from the ethnic political conjectures. A vivid example to

${ }^{172}$ Article from Jean Pierre Lehman, "The failure of Islam to Reform”, “The Globalist”, 2014.

173 Robin Right, “Two Visions of Reformation,” Journal of Democracy” 1996 pg. 64-75

174 Oliver Roy “Globalizimi i Islamit”, botimet “IDK”, 2004, pg.47 
illustrate this is the conflict between Israel and Palestine, which is utterly a religious and ethnic conflict since in its genesis.

Nevertheless, from 1995, the states engaged in a serious campaign to suppress the religion-based organizations. In 1997 the president of Jordan undertook a wide range of administrative reforms to nationalize about 1500 schools. The same thing was carried out by the government of Pakistan, which drafted a comprehensive plan to put under control the religious-based schools. In this perspective it can be argued that Pan-Islamism must be analyzed in a multidimensional approach. It is basically an ideology that seeks to give priority to Arab and Islamic states that persist to take economical, cultural autonomy against the western states and Israel.

The essential meaning of Pan-Islamism a privatization of Islam. It may be considered an ideology that has calls for a sociopolitical solidarity among Muslims and a concept that has existed since the genesis of Islam. ${ }^{175}$ The main demands of the modern neo-fundamentalists are as follows; a) to draft a constitution that provides supremacy Shari at b) to have the right to reject any judicial verdict on behalf of Shari at. This campaign aims to provide the Shari at judges to act in accordance to Shari at Right. ${ }^{176}$

\section{Causes that led to the birth of terrorist organizations in the Middle East.}

Undoubtedly, most of the terrorist activity has its roots in the region of Middle East. According to the renowned scholar of International Relations Karen Mingst, this has happened as a result of three main factors: ${ }^{177}$

a) In the claim of Palestinians for self-determination, and their inner conflicts about the strategy

b) In the enmity between different Islamic groups against the western powers

c) In the revival of Islamic fundamentalism

The remarkable scholar Marina Ottaway, argues that to fight ISIS, (Islamic State) is not enough to possess only military capacities, but it clearly demands even specific well-oriented political strategies. ${ }^{178}$ The Muslims who are oriented to extremism have to be well-educated in order to learn about the true values of their religion. It's true that ISIS ought to be fought by military means but even political strategies play a crucial role. The birth of ISIS has happened due to three main reasons. Firstly, it is a proto-state, which means that it is a political entity which does not represent a fully institutionalized sovereign state, and its borders are not determined. Secondly, United States and Europe intervened in Iraq only when ISIS had occupied Mosul. Thirdly, it would be better if it was named the "State of Mind", owing to the fact that it utilizes anger, disappointment, the idealization of youth, ardent enthusiasm towards religion and loss of hope at young generations for a better future. Moreover, this state is trying hard to put under control the minds of thousands of people on the west to fight in Syria and Iraq or to commit terrorist acts in their respective countries under the veil of misleading devilish ideals.

175 Oliver Roy “Globalizimi i Islamit”, botimet "IDK”, 2004, pg.47

${ }^{176}$ Oxford Islamic Studies Online

177 Karen Mingst, "Bazat e Marredhenieve Nderkombetare", botim i "Institute of International Relations".

178 Marina Ottaway, “Middle East Program”, Wilson Center, 2015. 


\section{Conclusions}

1. In the course of XX Century there is broad scope of factors that lead to a conflict between Islam and the West, they are as follows;

- The emerge of tyrant regimes that vary from traditional autocracies until dictatorial regimes, that use the oppressive apparatus and Islamic indoctrination.

- The impoverishment and increase of population in the Arab states.

- The struggles of the western world to universalize the values of their institutions, to increase their military and economic capacities in the Muslim world and to intervene in their domestic affairs have utterly angered the Muslims.

- The Islamic Revival is portrayed as distinctive quality, that makes them different from the others

- The fall of Communism, which was their common enemy, had a strong effect in the subsequent global developments. Due to this Islam and the West saw each other as opponents to each other.

- For many centuries the Islamic world has been a "leader" in many fields such as science, military power and culture. This is the reason why Islamic radicals blame the west as the cause of their stagnation such as Europe, Israel, America and Christianity in entirety.

- The "Islamic Revival", means a wide intellectual cultural, social, and political movement. However it is an overwhelmingly a religious Islamic Revival in its essence similar to the protestant reformation of the XVI century. The difference between them is that Islam is incorporating religion with politics, (that's the reason why its commonly referred to as political Islam"), it means in other words a strict and rigid implementation of Shari at the Islamic Right in political and judicial institutions. Contrary to this, the western world is based on secularity concerning the political and judicial institutions.

- The Radicalization and Islamic Fundamentalism has lead to the creation of a wide range of terrorist organizations aiming to use violence to attain to their objectives. They are Al-Qaeda, Hamas, Hezbollah, and Islamic State which has emerged the recent years. It comprises a serious problem and is a potential threat to peace in the western and Arab world.

\section{References}

1. Bernard Lewis, “ Ku po shkojme, Islami, Perendimi, dhe Moderniteti”, botim i "Shtepia Botuese e Librit dhe e Komunikimit”, 2004.

2. Article by Jean Pierre Lehmann, "The failure of Islam to reform", "The Globalist", 2014.

3. Yevgenia Baraz "Islamic Modernism, responses to western modernization, the Middle East", Boston, 2010. 
4. Faared Zakaria e "Ardhmja e Lirise", botim i "Instituti i Dialogut dhe Komunikimit", 2004.

5. Samuel Huntington "Perplasja e Qyteterimeve dhe riberja e rendit boteror", Shtepia Botuese, Logos, 2004.

6. Oliver Roy "Globalizimi i Islamit", botimet "IDK", 2004.

7. Robin Right, "Two Visions of Reformation," Journal of Democracy” 1996.

8. Oxford Islamic Studies Online

9. Karen Mingst, "Bazat e Marredhenieve Nderkombetare”, botim i "Institute of International Relations".

10. Marina Ottaway, “Middle East Program”, Wilson Center, 2015. 